\section{EMBRYRIDDLE}

Aeronautical University

SCHOLARLY COMMONS
Journal of Aviation/Aerospace

Education \& Research

Volume 4

Number 2 JAAER Winter 1994

Article 6

Winter 1994

\title{
Graduate Education in Airport Administration: Preparing Airport Managers for the 21st Century
}

Lawrence J. Truitt

John A. Hamman

Klaus G. Palinkas

Follow this and additional works at: https://commons.erau.edu/jaaer

\section{Scholarly Commons Citation}

Truitt, L. J., Hamman, J. A., \& Palinkas, K. G. (1994). Graduate Education in Airport Administration:

Preparing Airport Managers for the 21st Century. Journal of Aviation/Aerospace Education \& Research, 4(2). https://doi.org/10.15394/jaaer.1994.1123

This Article is brought to you for free and open access by the Journals at Scholarly Commons. It has been accepted for inclusion in Journal of Aviation/Aerospace Education \& Research by an authorized administrator of Scholarly Commons. For more information, please contact commons@erau.edu. 


\title{
GRADUATE EDUCATION IN AIRPORT ADMINISTRATION: PREPARING AIRPORT MANAGERS FOR THE 21st CENTURY
}

\author{
Lawrence J. Truitt, John A. Hamman, and Klaus G. Palinkas
}

Growing numbers of students pursuing management careers in aviation are seeking graduate degrees to prepare for the complex and evolving challenges in the aviation industry. This study questioned members of the American Association of Airport Executives (AAAE) about their profession and the appropriateness of current education opportunities in aviation administration. The purpose of this study was to identify the knowledge and skills that the next generation of airport administrators will need to effectively contend with the new industrial environment.

\section{INTRODUCTION}

The challenges in aviation are indeed enormous. Today the U.S. aviation industry is experiencing unprecedented turmoil from the combined effects of deep reductions in defense spending and a weak domestic and global economy. Despite these negative pressures, experts predict that demand for commercial air travel will nearly double by the year 2000 (FAA, 1992a, 1992b). As the industry recovers, many analysts forecast increased congestion at several large metropolitan airports (Wells, 1992). Congested hub airports not only produce costly disruptions to their own passengers, but also cause delays at other airports across the country as bottlenecks rebound throughout the system (GAO, 1991). To overcome the congestion problem, virtually all major airports and many smaller airports have expansion plans under way (Hardaway, 1991).

Expanding existing airport capacity to accommodate the predicted rising demand, while also ensuring safety standards, complicates the already difficult problems airport managers face in meeting environmental standards and addressing the complaints of various citizen groups (Jeffrey, 1991). Thus, expertise and training in environmental issues is a prerequisite for tomorrow's airport managers.

This article discusses how aviation education is adapting to meet these challenges. The article describes the program that was evaluated by the AAAE managers and provides an analysis of their assessments. We then draw some conclusions about the appropriateness of a current graduate curriculum in aviation administration and discuss possible improvements in light of comments made by managers.

\section{THE AVIATION MANAGEMENT CONCENTRATION} IN PUBLIC ADMINISTRATION

There are currently only a few schools offering Master's degrees in Aviation Management, including Embry-Riddle Aeronautical University, Central Missouri State University, and Southern Illinois University at Carbondale (SIUC). Others are sure to develop their own graduate aviation management curricula. In this study, we asked AAAE administrators to evaluate the graduate curriculum offered by SIUC, a specialized concentration in aviation administration in a Master's of Public Administration (MPA) program.

\section{Course Requirements}

Students in the MPA aviation concentration complete 42 semester hours of study. The program includes 15 hours of core public administration coursework, 12 hours of study in aviation courses, six hours of electives, and a three hour research paper.

The 12 semester hour aviation administration requirement consists of two components: nine hours of coursework in Aviation Policy and Administration and three hours in Quantitative Techniques. In addition, electives allow students to tailor their education by completing courses offered by other departments and colleges.

During their final semester, all MPA students design and complete a research project that typically expands on 
a research paper prepared for a core aviation seminar.

In addition, a public service internship requirement during the student's final semester provides a capstone for the MPA aviation concentration in public administration.

\section{THE AAAE AIRPORT MANAGER} SURVEY

In 1993, we mailed surveys to 698 airport managers who were members of the AAAE. The study specifically asked airport managers to evaluate the usefulness of the MPA program's curriculum and internship program. The survey also included questions about AAAE administrators, their career paths, and their educational backgrounds. Finally, the survey asked airport managers to make recommendations for improving the MPA program's courses. Of the 698 members contacted, 256 returned completed surveys for a response rate of 37 percent.

The Managers

The typical airport manager is a white male, about 47 years old. The range in ages was from 24 to 77 . More than half of the managers had been employed as managers of their airports six years or less. An overwhelming 94 percent of the respondents were males, and more than 96 percent were Caucasians. That airport administration is dominated by white males is no surprise to anyone who has attended a Federal Aviation Administration (FAA) or AAAE conference. However, this finding also indicates that aviation presents an enormous opportunity for qualified women and other minorities, given that society's acceptance of multiculturalism and diversity is desirable (Dewitt, 1994). In addition, the discipline of public

Table 1

Rank Scale

MPA Core

Management

and Evaluation

and Behavior
Airport Manager Rankings of Aviation Curriculum

$$
\begin{array}{lllll}
1 & 2 & 3 & 4 & 5 *
\end{array}
$$

The Environment

$\begin{array}{llllll}\text { of Public Administration } & 1 & 6 & 21 & 37 & 35\end{array}$

Public Budgeting

and Fiscal Management

Public Personnel

$\begin{array}{lllll}2 & 3 & 20 & 42 & 33\end{array}$

Program Analysis

$\begin{array}{lllll}2 & 7 & 41 & 32 & 18\end{array}$

Organization Theory

$\begin{array}{lllll}1 & 12 & 45 & 30 & 13\end{array}$

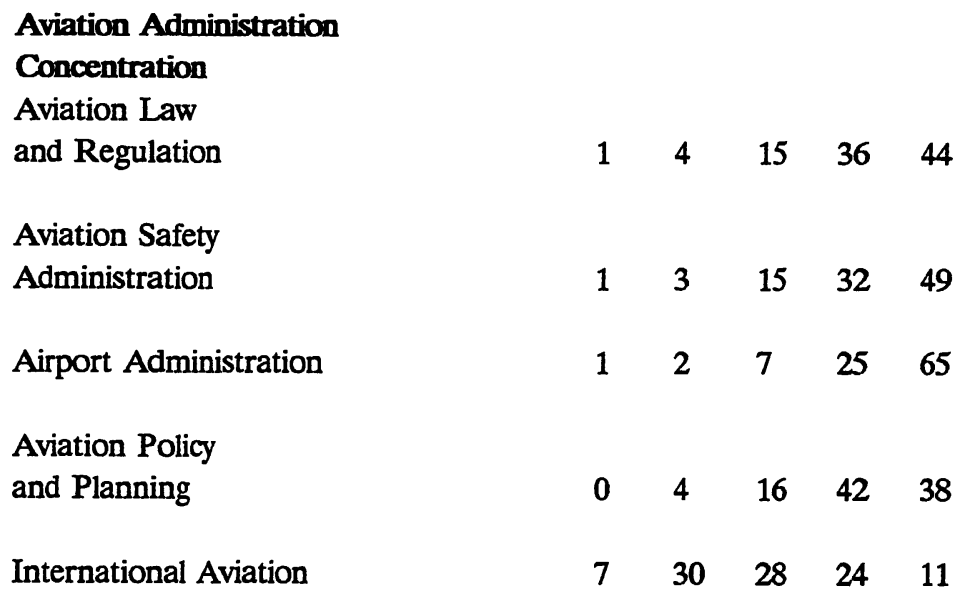

*(1=not relevant, $5=$ =xtremely relevant $)$

Source: SIUC/MPA national mail survey of AAAE airport managers

administration has long recognized that our public work force should reflect the composition of the public it serves. Minorities have been quick to respond to this opportunity by forming their own groups, such as Women in Aviation.

The educational background of the typical airport manager is high but diverse. More than 80 percent of the 
airport managers surveyed earned college degrees in a variety of fields, including public administration, business administration, aviation, engineering, the sciences, and liberal arts. More than half pursued graduate work in one of these fields. To illustrate the increasing professionalism in the field, about one-third had earned graduate degrees.

Airport managers have also followed a variety of career paths. Nearly 60 percent had previous military experience and 51 percent were pilots. About a third noted they had previous professional experience in municipal government, with fewer reporting experience in air traffic control or in state and/or federal administrative positions.

Of course, every manager surveyed was a member of the AAAE. About one-fourth of the respondents belonged to the Airports Council International (ACI) and/or the Aircraft Owners and Pilots Association (AOPA). Less than 10 percent were members of public administration-oriented professional organizations such as the International City Manager Association (ICMA) or the American Society for Public Administration (ASPA). However, a new section on Transportation Policy and Administration within ASPA was chartered in 1993. This section now has more than 200 members, many of whom are experts in aviation administration.

Manager Assessments of MPA Aviation Curriculum

The study was interested in active practitioners' assessments of educational needs in aviation. The survey asked airport managers to rate the relevance of each course in the MPA core curriculum and the specialized courses in the Aviation Administration concentration on a scale of 1 to 5 , with a score of 1 indicating "not relevant" and a score of 5 indicating "extremely relevant." Table 1 reports the percentage of managers assigning scores for each of the course offerings.

A complete description of the contents of each course was not included in the survey instrument. Thus, respondents were asked to rate courses based only on the titles of the courses. This lack of information on the subject matter clearly made it impossible for managers to make absolute assessments. Nevertheless, the titles conveyed the essence of the course and the airport managers' assessments were found to be extremely useful.

The managers reported that all the MPA courses were relevant to the profession. Most of the scores were 3 or higher (International Aviation is an exception). However, airport managers clearly found some courses more relevant than others. Of the mainstream public administration core courses required for all MPA students, including students concentrating in aviation administration, Public Budgeting and Fiscal Management was ranked the highest, with 62 percent of the respondents indicating a score of 5 , or "extremely relevant," and 28 percent rating it a 4 . Clearly, more emphasis on budgeting and finance in core courses is called for.

The managers ranked the courses in Public Personnel Management and the Environment of Public Administration next highest, with more than 70 percent of the airport managers rating both courses either a 4 or 5. A follow-up question that asked respondents how the program might be improved made it clear that simply listing the courses by title failed to provide readers with enough information on the content of the courses. Thus, many airport managers suggested that more training in areas such as labor relations or ethics was needed. However, these topics are central components of existing courses.

Airport managers generally considered the aviationspecific courses to be more relevant than the core public administration courses. Not surprisingly, the Airport

\section{Table 2}

Frequency of Suggestions for Improvements

Recommendation Category

Regulation

Communications/Marketing

Contract Administration

Civil Engineering

Operations

Economics

Miscellaneous

$\mathrm{n}=185$

\section{Percent}

25

18

18

6

6

5

$\frac{22}{100}$ 
Administration course was most important to them, with 65 percent of the respondents rating the course a 5 and 25 percent rating it a 4. Aviation Safety Administration, Aviation Law and Regulation, and Aviation Policy and Planning followed closely, all of which got at least a score of 4 from more than 80 percent of the respondents. The course in International Aviation received the lowest rating of the aviation-specific courses. This lower rating is not surprising because the vast majority of respondents manage small general aviation airports and international aviation is not relevant to many of them.

\section{Manager Recommendations}

Based on their assessments of the current aviation concentration curriculum, the managers were asked to suggest additions or deletions to the existing program. Of the 256 respondents, 109 AAAE member-managers (43\%) made more than 185 specific suggestions, which we grouped into the seven categories listed in Table 2. With only one exception, managers saw the need to make additions, not deletions, to the program.

\section{Law and Regulations}

About 25 percent of the comments concerned law and regulations. More than one-half of the respondents stressed the importance of providing students with a background in environmental regulations and their implications for airport planning and development. Airport managers singled out the execution of Environmental Assessments (EAs) and Environmental Impact Statements (EISs). The importance of mastering environmental law, liability, and policy concerns was also mentioned by many of the managers. One manager suggested there should be a course on hazardous materials. Five managers emphasized learning how to contend with airport noise regulators.

Several managers singled out FAR Part 139 (airport safety certification) for explicit treatment in the curriculum. Others suggested that FAR Part 107 (airline passenger security) needed additional emphasis. Four managers stressed that an understanding of the FAA rule-making process as it pertains to Airworthiness Directives (ADs) and safety Advisory Circulars (ACs) needed further emphasis. In addition, several mentioned FAA regulations generally, and one respondent noted litigation avoidance.
Nine respondents wanted to see greater attention to aviation law, with emphasis given to the FAA-delineated airport master planning process (four references). Two others specified detailed study of the FAA-funded Airport Improvement Program (AIP), including one reference to AIP strategies and another to general strategic planning and airport development.

\section{Communication Skills and Marketing}

Many managers mentioned the need for students to improve written and oral communication skills where marketing and public relations are concerned. Fifteen respondents couched their suggestions in general terms, emphasizing written and oral communication skills, communication ability, or public relations. Five emphasized public speaking and presentation skills.

Several were more explicit, emphasizing the critical importance that airport managers be able to effectively communicate with their employees, the governing boards, and the community the airport serves. One manager observed that airport managers must also be adept at communicating with aviation professionals and public constituencies.

Thirteen others identified public relations, media relations, public affairs, and public awareness as important skills. Another mentioned the importance of maintaining good relations with airlines.

\section{Contract Administration}

Responses in this category centered on general negotiation skills, particularly as they relate to contract administration, property management, and labor administration. About 20 percent of the managers suggested that more treatment be given to contract administrative skills in property management, real estate, and labor administration. Responses tabulated as contract administration in the property management sub-category outnumbered references to labor administration more than two-to-one.

In particular, respondents suggested that educators need to teach more about conflict resolution techniques, minority hiring programs, and labor union relations. Managers also frequently mentioned lease development, lease negotiation and administration, real estate law, business and property management, and airport terminal area leasing. 


\section{Civil Engineering}

Several respondents mentioned the need for understanding basic civil engineering skills. Six managers singled out runway and taxiway signage, pavement strength, and lighting systems. Other airport managers emphasized the need to offer instruction in civil engineering concepts. Still others wanted to see courses focus more on the basics of airport engineering and civil engineering.

\section{Operations}

About 5 percent of the respondents recommended more emphasis on operations in the curriculum. For example, two respondents suggested more classroom treatment of navigational aids and maintenance. Two other respondents wanted more treatment of systems planning. Another airport manager thought our curriculum needed to focus more generally on operations. One manager emphasized teaching FAA guidelines for minimum standards for airports. Two others underscored the importance of mastering emergency operations, safety, and planning. Two managers also noted the importance of incorporating security issues into the curriculum. One manager thought it was important to clearly distinguish between the needs of general aviation and air carrier operations.

\section{Economics}

Another 5 percent of the suggestions addressed the need to provide students with a better understanding of basic aviation industry economics. Three managers mentioned that the program should provide more coverage on the economics of airports, fixed base operators, and airline service development. Six others saw the need to teach general business law, business cycles, and business trends.

\section{Miscellaneous Administrative Skills}

A difficulty was encountered in categorizing more than 20 percent of the remaining suggestions for improving the MPA curriculum. These included comments that the program give priority to teaching grant administration, grant writing, and technical writing. Five others felt greater attention should be given to teaching computer skills.

Several of the managers saw the need to provide more instruction in politics, the political environment, and political issues. A few managers suggested coursework in interorganizational, interpersonal, and intergovernmental relations. Others suggested that we add Political Science 101 to the core requirements. Others wanted us to ensure that students are able to distinguish politics from administration. Of course, these issues are at the heart of the discipline of public administration.

Several respondents suggested that the MPA program incorporate elements of the $\mathrm{AAAE}$ professional accreditation process into the curriculum. One respondent justified its inclusion by noting that the AAAE model of professional accreditation will likely be adopted at the international level. Another airport manager suggested that student attendance at state aviation conferences be made a mandatory part of the curriculum. A third manager suggested incorporating study of new global positioning system technology (GPS or satellite navigation) into the curriculum. Three respondents suggested that the curriculum be made available off-campus through correspondence or other means.

Finally, one manager insisted that the program include a component on airframe and power plant maintenance. Another expressed dismay at the low number of airport managers with pilot qualifications and suggested that prospective airport managers be required to have at least soloed a single-engine aircraft. Only one respondent suggested a deletion: to drop the historical portion of aviation law.

The managers told us repeatedly that knowledge of government regulations and business law is paramount to their work. Likewise, superior oral and written communication skills are essential to effective administration. To a lesser extent the respondents emphasized conceptual knowledge of navigation, civil engineering, and general airport operations.

\section{DISCUSSION AND CONCLUSIONS}

The airport managers surveyed heavily favored courses in which practical applications were apparent in the course name. They tended to assign the highest scores to courses such as Public Budgeting and Fiscal Management and Aviation Safety Administration.

Airport managers were less enthusiastic about courses that address the more theoretical aspects of the 
administrative sciences. Both in their scale-rankings of MPA courses and in their open-ended responses, the managers struck a dichotomy in course relevance between theory and practice. Airport managers decidedly preferred courses such as Public Budgeting and Finance, Aviation Safety Administration, Public Personnel Management, Airport Administration, and Aviation Policy and Planning.

On the other hand, they found courses such as Organization Theory, Program Analysis and Evaluation, and Environment of Public Administration less relevant. On the survey instrument, airport managers frequently penciled in question marks or made notes indicating that they were uncertain about the content of less favored courses. Many appeared to confuse the theoretical connotation of the term "environment" in the course title with environmental regulations as promulgated by state and federal environmental protection agencies. Perhaps a different title for this course, such as Principles or Foundations of Public Administration, would more accurately describe the course content. The confusion over content, however, likely distorts this course's comparatively high third-place ranking behind Public Budgeting and Personnel Administration.

Similarly, the comparatively low values placed on such courses as Program Analysis and Evaluation and Organization Theory may also reflect an incomplete understanding of the content and purpose of the courses. Some of the remarks volunteered by the respondents in the follow-up open-ended question would seem to bear this out. For example, several managers suggested that we teach ethics, responsibility, and leadership, topics that are currently covered in the organization theory and personnel classes.

The more theoretical public administration courses lay the intellectual foundation for the development of leadership skills. This foundation provides a sound understanding of the fundamental process that drives policy formulation and implementation in American government. Therefore, these core public administration courses provide the basis for sound managerial decisionmaking abilities. In the practical terms favored by many survey respondents, this theoretical foundation also provides other skills they emphasized, including the ability to distinguish politics from administration, understanding the legislative process, and understanding political issues.

Moreover, the theoretical courses address yet another category of concern regarding the need for effective communication and related skills voiced in the responses. These include emphasis on the understanding of and interaction with the airport manager's diverse public, including employees, boards, agencies, airport users, and nearby residents. The theoretical courses provide the conceptual foundation that is necessary for managers to successfully relate to the community and other governmental agencies. Along the way, the students also receive training in public speaking and the delivery of presentations, as well as considerable practice in other forms of written and oral communication. In sum, the theoretical courses provide the basic foundation for understanding the concept of the public interest, which is essential for the profession of public administration. In doing so, theoretical aspects of the curriculum satisfy this category of concern expressed by the airport managers.

Survey participants' evaluations of Aviation Law and Regulation and International Aviation require special comment. Most respondents emphasized study of Federal Aviation Regulations (FARs) and other legal and regulatory aviation requirements. Yet this subject matter is covered in the existing course, Aviation Law and Regulation. The managers' concern can be construed as agreement with the curriculum designers on essential core elements.

The aviation law course also includes a review of the historical aspects of transportation law and regulation, which were recommended for deletion from the curriculum. We found the suggestion curious, to say the least. Because the field of law is dynamic and builds upon precedents established in earlier cases, we believe that a historical review of both common and statutory law is an essential component in graduate aviation education.

The comparatively low ranking of the International Aviation course reflects the strictly local or regional interests of the large number of general aviation airport managers represented in the survey. Those airport managers who put high values on the International Aviation course were managers of large airports that 
serve international carriers. The small percentage of international airports in the survey population reflects the proportion of large hub airports with scheduled international airline traffic among the nation's total airports-only 2.2 percent (AOPA, 1993). In fact, it was in recognition of aviation's trend toward increasing globalization that the course in international aviation was added to the curriculum.

Survey respondents emphatically stressed real estate, property management, and contract negotiation skills. They emphasized that real estate law, real estate leasing administration, and contract negotiation, are among implicitly required property management skills. The managers also emphasized airline relations and negotiating skills, including information about the leasing of gates and related facilities at larger airports. Contract negotiation skills were also extended into the labor relations arena by some respondents. This important area could justify an entire course. However, these skills can be incorporated into existing courses, such as Public Budgeting, Advanced Airport Administration, and Public Personnel Management.

In summary, the survey was extremely helpful in learning how airport managers view the MPA graduate aviation administration program. The respondents' suggestions for designing course materials offer clear guidance for educators.

The respondents voiced solid support for the notion that an MPA aviation concentration gives students the necessary broad background to adapt to the evolutionary changes in the political economy and the revolutionary changes in the aviation industry. The dramatic changes in the aviation industry provide clear evidence that a new standard of excellence in higher education is necessary for America to maintain its position as the world's leader in aviation.

Lawrence J. Truitt received a Ph.D. in Public Administration from Arizona State University in 1991. He is an Assistant Professor in the MPA program at Southern Illinois University at Carbondale and teaches Aviation Management, Aviation Planning and Policymaking, International Aviation, and Intergovernmental Relations.

John A. Hamman received a Ph.D. in Public Policy and Public Administration from the University of Illinois at Urbana with a concentration in transportation policy in 1988. He teaches program evaluation and policy analysis for the MPA program at SIUC.

Klaus G. Palinkas is an aviation consultant for AvCon in its Orlando office. He holds an MPA degree in Aviation Administration from Southern Illinois University and a B.S. degree in journalism from the University of Illinois.

\section{REFERENCES}

Aircraft Owners and Pilots Association. (1993). Aviation statistics. Aviation USA. Frederick, MD: AOPA. Dewitt, D. (1994, Winter). Thinking about diversity. National Forum, 74(1), 19.

Federal Aviation Administration. (1992a). Second annual FAA general aviation forecast conference proceedings. FAA/APO 92-3. Washington, D.C.: U.S. Government Printing Office.

Federal Aviation Administration. (1992b). FAA aviation forecasts: Fiscal years 1992-2003. FAA/APO 92-1. Washington, D.C.: U.S. Government Printing Office.

General Accounting Office. (1991). Meeting the aviation challenges of the 1990s. GAO/RCED-91-152. Washington, D.C.:

U.S. Government Printing Office. 
Hardaway, R. M. (1991). Airport regulation, law, and public policy. Westport: Quorum.

Jeffrey, D. (1991, July/August). The environmental reality: Prison anyone? Airport Magazine, p. 18.

Wells, A. T. (1992). Airport planning and management. Blue Ridge Summit: Tab Books. 